man who probably knew his "Plains" better than any other, but also a genuine effort at co-ordination and presentation of the results of carefully focused investigations. It might, however, have been substantially improved by a more complete summary of the present position of our knowledge, by way of introduction to the several contributions, than is attempted in the brief foreword; this, though sufficiently lucid so far as it goes, still leaves to the reader the task of fitting together the various pieces of evidence to make a pleasingly intelligent picture of the whole.

\section{Index of Publications of the Royal Society}

THe Royal Society has issued in one alphabet an author index to its Proceedings, Series A and B, from 1905 to 1930 , and to the Philosophical Transactions, Series A and B, from 1901 to the same year, the entries being arranged chronologically under each heading. A previous index to the Proceedings was published in 1913, which covered the period from 1800 (when the series began under the title "Abstracts of Papers printed in the Philosophical Transactions") to the year 1904, so that the author index to this publication is now complete to the year 1930. The only indexes to the Philosophical Transactions hitherto available have been author and subject indexes down to the year 1830, but the "Catalogue of Scientific Papers", which includes papers in the Philosophical Transactions, may be considered to continue the indexing under authors' names down to the year 1900, whence the new volume completes it to the year 1930 . So far as the author index is concerned, therefore, the indexing of the two publications is available for their entire runs. A subject index from 1800 is still lacking, except in so far as the mathematical, mechanical, and physical papers for the period 1800 1900 are concerned, since these have been included in the three published subject indexes to the "Catalogue of Scientific Papers", which covers both publications.

\section{Science and Letters in Poland}

THE principal contribution to vol. 15 of Nauka Polska (Polish Science), which has recently appeared, is Prof. Z. Szweykowski's account of the Institute for the Promotion of Science and Letters in Poland. This Institute, which is to-day under the patronage of Prof. I. Mościcki, the President of the Polish Republic, and himself a distinguished chemist, was founded in 1881 in difficult circumstances from the Mianowski Fund. It has had a chequered history, but the Mianowski Institute now occupies the spacious Staszic Palace, and its future is assured. The aim of this Institute is the furtherance of all branches of science in Poland. It has already published or supported financially the publication of 1200 volumes and the preparation of 200 scientific works, and has subsidised fifty scientific periodicals. In addition, it has made grants to some fifty societies, research laboratories, and museums. The same volume of Nauka Polska includes a comprehensive survey of the progress of science in Poland between 1800 and 1880 by Prof. F.
Bujak. It constitutes a summary of the works of Polish men of science during the greater part of last century. Other articles deal with the present-day needs of applied physics, the position of the State libraries in Poland, and the scope and organisation of the Institute for Slavonic Studies.

\section{Habits of Bats}

IN the Journal of Mammalogy for May (p. 133) Mr. C. E. Johnson gives some notes on a family of red bats (Lasiurus borealis borealis) in captivity, and mentions that theold female, when let looseindoors, alighted more than once on the floor, and rose as easily as a bird. In the eighteenth century, Gilbert White alludes to a tame bat he saw, which several times confuted the vulgar opinion that bats could not rise from a flat surface, by rising with great ease from the floor; and the writer of this note has found the common yellow bat of India (Nycticejus kuhli) and the collared fruitbat of Africa (Rousettus leachi) also quite able to take wing from the flat. These examples are worth giving because the error mentioned by White still persists, and in quarters where 'vulgar opinion' might not be supposed to be the vogue. The fact is that a bat does not voluntarily remain on the flat in the open, but may no doubt be found there unable to rise owing to some incidental disability, just as a man may be found lying helpless on a pavement for a similar reason.

\section{Safety in Mines}

THE Safety in Mines Research Board has recently issued its tenth Annual Report, which contains a good. deal of matter of scientific interest. Perhaps the part that will be most widely read is Appendix No. 9, which refers to researches intended to obviate fatalities from falls of ground. It commences by a record of researches on the strength of supports, etc., carried out under the direction of Prof. S. M. Dixon, and, furthermore, contains summaries of the results obtained by the various district committees working on the subject throughout Great Britain. The body of the Report shows considerable activity on the part of the Board, and indicates how greatly the scope of the work has been extended and how much has been done to make the results accessible to mining men generally. It must, however, be admitted that the work so far has been rather of the nature of collecting scientific material which will, no doubt, be useful at some future date in increasing the safety of mining, for up to the present the results obtained are of scientific interest rather than of practical importance.

\section{American Railway Progress}

THE issue of the Journal of the Franklin Institute for March contains the address of Mr. W. C. Dickerson, president of the American Locomotive Company, on the progress made during the interval 1920-30. The 15 charts reproduced allow it to be readily seen. The weight on the driving wheels of the goods locomotive has increased from 245 to 247 thousand pounds, but the drawbar pull, at 28 miles an hour, from 32 to 50 thousand. For the passenger locomotive the corresponding figures are 192 to 187 and 18 to 44 thousand 
poun ds, at 60 miles per hour. Engine runs have been increased from 140 to 400 miles, crews being changed at intervals. As a result there are fewer locomotives in use to-day than ten years ago. Goods waggons have increased in size and decreased in number, and ordinary passenger coaches have been replaced by Pullman cars. The ton miles for goods have risen from 410 to $447 \times 10^{9}$, but the passenger miles have fallen from 47 to $31 \times 10^{9}$. Revenue increased from $6 \cdot 2$ to $6.3 \times 10^{9}$ and operating expenses decreased from $5 \cdot 8$ to $4.5 \times 10^{9}$ dollars. Mr. Dickerson is not satisfied that 45 per cent of the locomotives in use are more than twenty years of age He shows that it is in the end more economical to replace old locomotives rather than to rebuild them. He considers that the diesel-electric locomotive has a wide field of usefulness.

\section{Smoke Abatement}

ThE Quarterly Journal of the National Smoke Abatement Society, issued by the Society, 23 King Street, Manchester, among other things analyses the progress of smoke abatement as revealed by the latest Report on Atmospheric Pollution issued by the Department of Scientific and Industrial Research. This records for the average of a number of stations a decrease in 'total deposits', in tar, and sulphate averaging 16 per cent, 24 per cent, and 19 per cent respectively. While this decrease may partly be due to industrial depression, it is concluded that there has been a definite reduction of domestic smoke. Some of the figures, if correct, suggest that current ideas require revision. While the atmosphere of industrial cities seems to be improving, conditions in London get worse, and now appear to be similar to those of Hunslet-an industrial area in Leeds. Again, the suburbs of Leeds yield figures better than those of Southport. Such comparisons will suggest the need for caution in interpretation, but the figures show that conditions can be improved, and the Journal does a good service in emphasising this.

\section{Food Technology}

REFERENCE has previously been made in these columns to the problems of food preservation and their importance to modern civilisation. The more scientific aspects of the subject are dealt with in the reports of the Food Investigation Board and the Empire Marketing Board, and references to the extensive literature on the subject can be found in the "Index to the Literature of Food Investigation". Food Technology is described as a monthly review of manufacture, packing, and transport for production managers, food chemists, and engineers, and is designed to make known the work of research centres and to secure greater publicity for their achievements. The journal contains articles on different aspects of the food trade, answers to readers' inquiries, and notes on recent patents, amongst other features. It appears that it should fulfil its object of keeping those engaged in modern food factories in touch with research work on the treatment of food, as well as with the necessary auxiliary trades. It is edited by Dr. H. D. Law, 153 Stratford High Street, London, E.15; price $12 s$. a year.

No. 3276 , VoL. 130$]$

\section{Best Books in 1930}

UNDER the title "Best Books of 1930 " a selected list of books published during that year has recently been issued by Mr. Alex. J. Philip, "Lodgewood", Gravesend, and Messrs. Simpkin Marshall, Ltd., London, E.C.4. The list is classified on the Dewey Decimal System and has been selected with the help of many authorities, institutions, and societies. The main headings of the classification include general, philosophy, metaphysics, religion, sociology, philology, science, arts, literature, and history, and these are subdivided into their various groups. About 2500 "Best Books" are thus classified for the year 1930 . Such a list should prove useful as a work of reference, and should be an asset to all lending and reference libraries, as well as to departmental and institutional libraries. Nevertheless, we venture to suggest that since the comparative value of a book is often a matter of opinion, such a selected list cannot be expected to be anything other than a tentative guide to choice.

\section{Announcements}

THE Third International Congress of Cytology will be held in Cambridge at the end of August 1933. Further particulars will be published in due course.

Mr. I. W. M. Armstrong-Black has been appointed assistant agricultural chemist, Nyasaland (Colonial Agricultural Service).

A sHort training course for curators and assistants has been arranged by the Museums Association to be held at Manchester on Sept. 27-30. The course will be devoted to the study of the technique and administration of science and art museums and galleries, and will include visits to the Manchester Museum at the University, the Manchester City Art Gallery and branches, the Whitworth Art Gallery, and the Royal Museum and Art Gallery, Salford. No fees will be charged for attendance. Applications for grants towards students' expenses in attending the course will be considered by the Committee and should be addressed to the Secretary, The Museums Association Short Training Course, Public Museum, Bootle.

ApPLICATIONs are invited for the following appointments, on or before the dates mentioned:- -An assistant agricultural chemist in the Department of Agriculture and Horticulture at the University of Bristol-Agricultural Advisory Office, 22 Berkeley Square, Bristol (Aug. 20). A lecturer in mechanical engineering at the Municipal Technical College, Hull -The Director of Education, Education Offices, Guildhall, Hull (Aug. 20). A principal of the Lester Technical School and Institute, Shanghai--The Secretary, Association of Principals of Technical Institutions, Chelsea Polytechnic, Manresa Road, S.W.3 (Sept. 1). An attendant for the Departments of Botany and Zoology at the North of Scotland

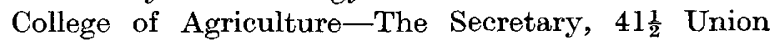
Street, Aberdeen. An assistant tobacco chemist in the Chemical Laboratories of the Ministry of Finance, Egypt--The Chief Inspecting Engineer, Egyptian Government, 41 Tothill Street, London, S.W.1. 